\title{
A New Species of Pedicularis (Scrophulariaceae) from the Yaoshan Mountain, Yunnan, China
}

\author{
Zhang Shu-dong \\ Laboratory of Biodiversity and Biogeography, Kunming Institute of Botany, \\ Chinese Academy of Sciences, Kunming 650204, China and Graduate School, \\ Chinese Academy of Sciences, Beijing, 100039, China. sdchang@mail.kib.ac.cn
}

\section{Wang Hong}

Laboratory of Biodiversity and Biogeography, Kunming Institute of Botany, Chinese Academy of Sciences, Kunming 650204, China. wanghong@mail.kib.ac.cn

\section{Roberl R. Mill}

Royal Botanic Garden Edinburgh, 20 A Inverleith Row, Edinburgh EH3 5LR, Scolland, United Kingdom. R.Mill@rbge.org.uk

Abstract. Pedicularis yaoshanensis H. Wang from Yunnan, China, is described and illustrated. The new species was found growing on wel cliffs, at high elevations in the Yaoshan Mountain. It is placed in Pedicularis series Longiflorae Prain. The main diagnostic features of $P$. yaoshanensis include its acaulescent habit, pinnatipartite leaves, calyx with 3 lobes (the posterior one smaller and tripartite), the deflexed galea beak pointing downward, and the two posterior filaments of the stamens glabrous. A key to similar species is given, and its relationships discussed.

Key words: China, northeastem Yunnan, Pedicularis, Scrophulariaceae.

Pedicularis I. is the largest genus of the family Scrophulariaceae as traditionally recognized (Mill. 2001). Between 600 and 800 Pedicularis species are distributed primarily in the Aretic and alpine regions of the northern hemisphere (Macior, 1988; Wang el al., 2003). At least 367 species occur in China (H.-B. Yang et al., 1998, and species subsequently published by Yamazaki, 2000, 2001, 2003: F.-S. Yang et al., 2003), where it is the fourth-largest angiosperm genus after Rhododendron I.., Carex I.., and Astragalus L. ( $\mathrm{Wu}$ et al., 2003). Pedicularis is best represented in the mountains of southwestern China. which represents one of the main centers of species diversity for the genus (H.-B. Yang et al., I998; Mill. 2001).

There are 152 species. including 5.3 endemic species, now recognized within the genus Pedicularis in Yumnan. China, which is a center of diversity and endemism (Li et al.. 2002: Wang. 2005). All fou corolla lypes recognized in Pedicularis by Li (1951) occur in Yumnan; his advanced corolla type with a beak and slender elongated tube is limited in its distribution to the Sino-Himalayan region, and only 16 species have these elongated corolla tubes in Yunnan.

Rising from the upper reaches of the Yangtze River, the Yaoshan Mountain lies in the border area between northeastern Yunnan and southern Sichuan provinces. During recent fieldwork by us, 17 species of Pedicularis were found in the Yaoshan Mountain. Of these, only the new species belongs to the advanced corolla type of Li (1951).

Pedicularis yaoshanensis II. Wang, sp. nov. TY PE: China. Yumnan: Qiaojia county, Yaoshan Mountain, $27^{\prime} 1 \mathrm{I}^{\prime} \mathrm{N}, 10304^{\prime} \mathrm{E}, 3600-3700 \mathrm{~m}, 17 \mathrm{Aug}$. 2004. Hong Wang \& Shu-dong Zhang 03-0857 (holotype, KUN). Figure 1.

Species nova cum P. latituba Bonati ef P. lobatorostrata T. Yamazaki (ser. Longiflorae) corollae labelli lobo mediano emarginato el galeae rostro apice bilobato congruens sed humilior subacaulis, pedicellis multo minoribus $1-2 \mathrm{~mm}$ tantum (non I0-20 mm), calyce minore 5-6 mm longo (non $8-10 \mathrm{~mm}$ ut in P. Latituba, $13-20 \mathrm{~mm}$ in P. Lobatorostrata). rostro galeae corollae minore $3 \mathrm{~mm}$ longo (non $5-6 \mathrm{~mm}$ ). filamentis posticis glabris differt.

Perennial dwarf clustered herb. to $6 \mathrm{~cm}$ tall including the flowers, sometimes drying slightly black: roots \pm lignified, long-conical, branched. 57 cm long. ca. $1 \mathrm{~mm}$ diam., drying brown: stems erect. much reduced and almost absent, only $5-10 \mathrm{~mm}$ tall, basally obscured by withered petiole bases and brown membranous scales. Leaves alternale. clustered; 

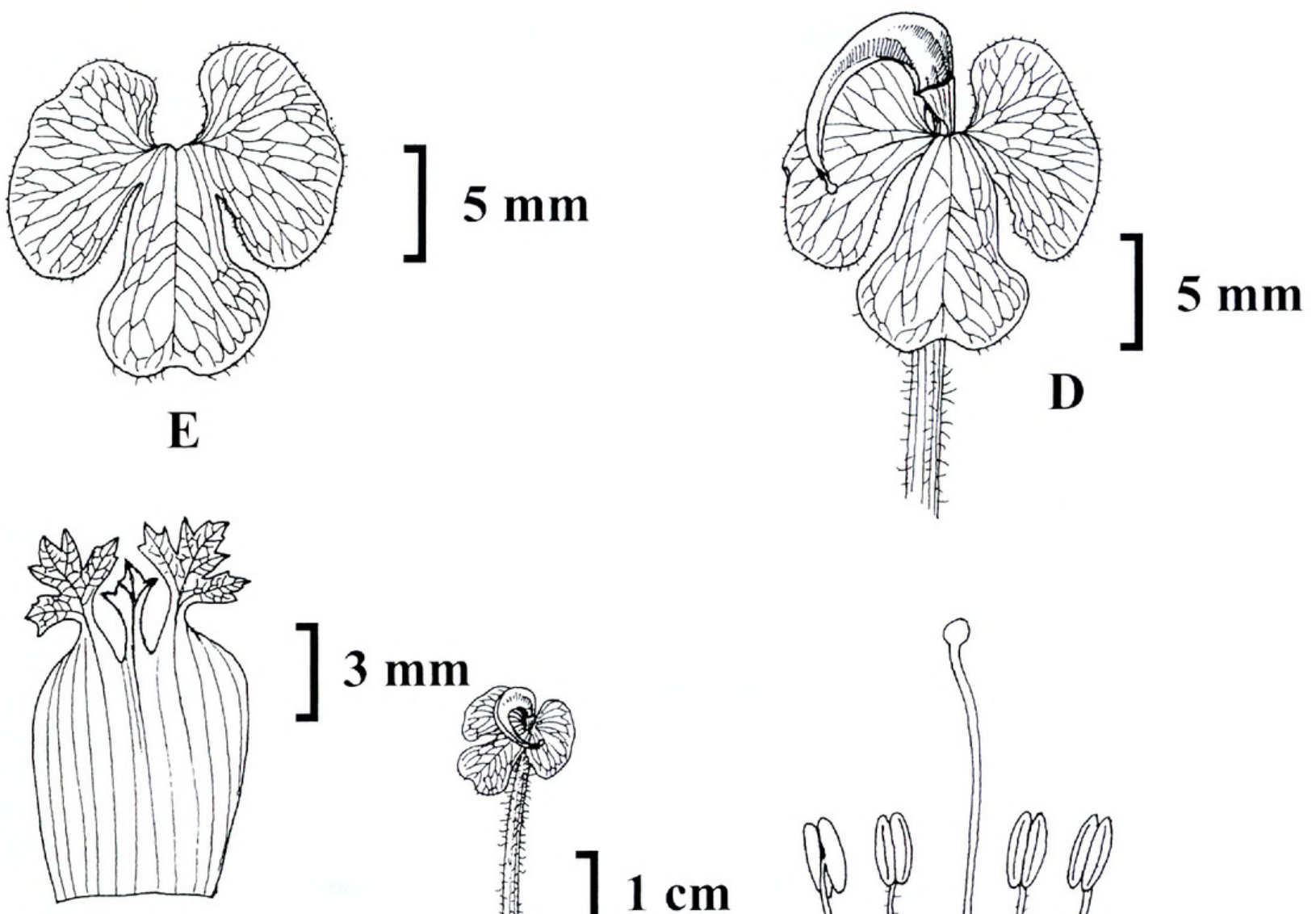

\section{$3 \mathrm{~mm}$}

C
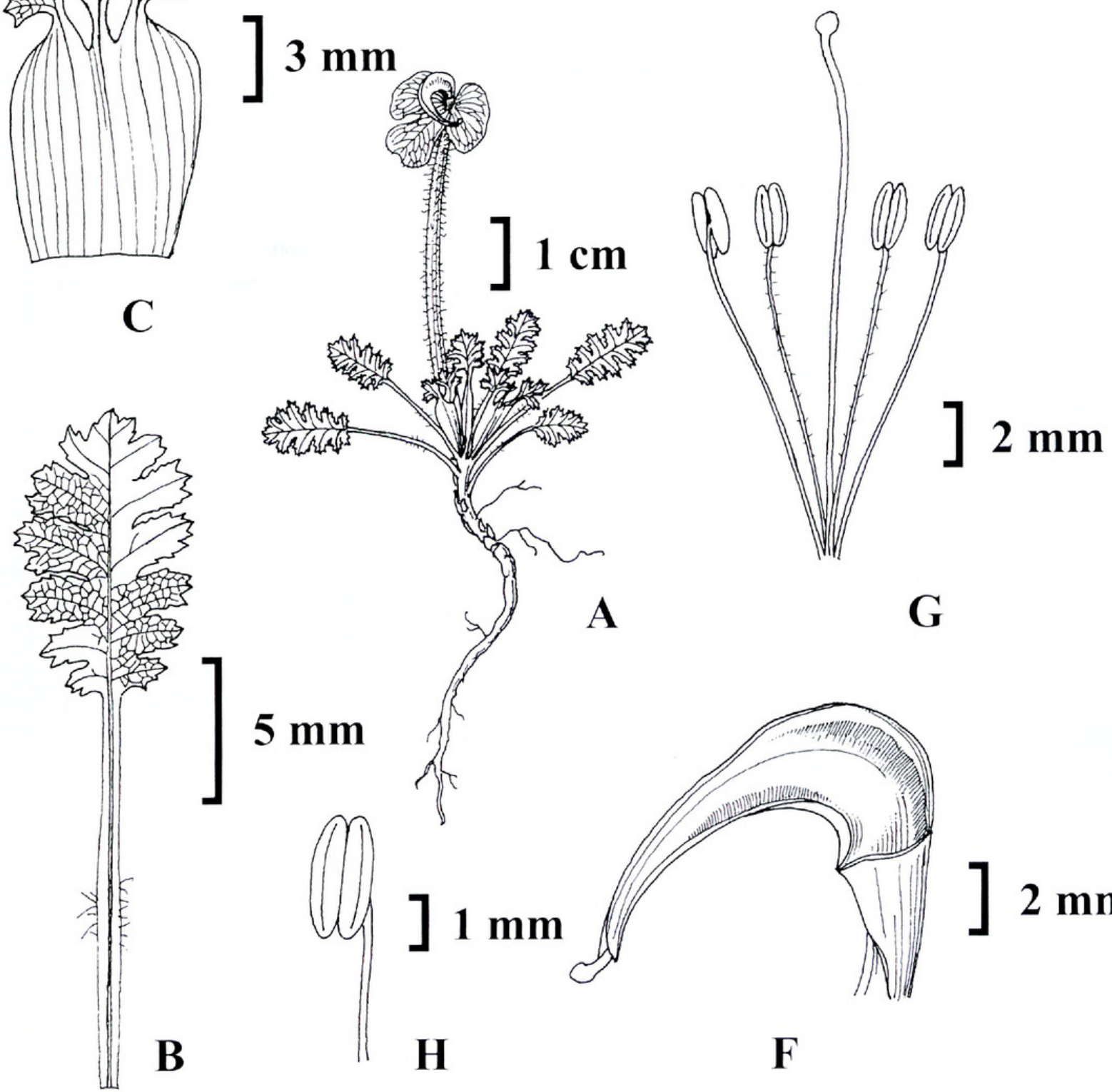

G

Figure 1. Pedicularis yaoshanensis H. Wang. - A. Habit. - B. Leaf. - C. Calyx opened out; posterior tooth in center. -D. Upper part of corolla tube and upper and lower corolla lips. _E. Corolla lower lip dissected out. —F. Upper lip (galea). — G. Stamens and style dissected out: anterior filaments furthest from style. - H. Anther and upper part of filament. Drawn by Xi-Lin Wu from the holotype, Hong Wang \& Shu-dong Zhang 03-0857 (KUN). 
petioles $10-20 \mathrm{~mm}$ long, drying yellow, widely membranous winged along their length, pilose only for a short distance in the middle, the proximal and distal portions glabrous: blades obovate-elliptic, 14 $17 \times 6-9 \mathrm{~mm}$, obluse at apex, glabrous, pinnatiparlite, with 3 to 7 pairs of segments, each segment to $1 \mathrm{~mm}$ long. serrate, shorlly cuspidate at apex, furfuraceous, with veins and veinlets prominent beneath. Flowers 1 to 4 , axillary, pedicellate. the pedicels 1-2 mm long, densely long-pilose; calyx campanulate. 9-10 mm long overall, the tube 5-6 $\times 4 \mathrm{~mm}$, densely long-pilose outside with trichomes ca. $0.1 \mathrm{~mm}, 1 / 3$ cleft anteriorly and slightly constricted at the mouth, membranous, with 3 prominent veins and numerous veinlets, 3-lobed, calyx lobes leaf-like, furfuraceous, the posterior lobe $2 \times 2 \mathrm{~mm}$. smaller than the lateral lobes but equaling or longer than their individual lobules, subelliptic but tripartite, attenuate into a long petiolule; lateral lobes 4 $\times 3 \mathrm{~mm}$, alternate, oblique and anisomerous at base, attenuate into short, broad petiolules, the upper foliaceous part expanded and orbicular in outline, tripartite, the lateral lobules oblong-obovate, each with 2 or 3 distal teeth, the terminal lobule of each lobe more broadly obovate and more deeply 3-toothed than the 2 lateral lobules; corolla crimson, with white throat; corolla tube 32-43 mm long. cylindrical, not dilated at the apex, densely pilose with thin hairs outside; the erect part of galea about as wide as the tube, gradually broadening above, slightly notched on anterior side at the apex and at almost 90 to the inflexed anther-bearing portion; anther-bearing portion of galea slightly protuberant, glandular; beak falcalely curved, ca. $10 \mathrm{~mm}$ long, obliquely pointing downward, 2-partite at apex, the lobules broadly band-shaped, ca. $2 \mathrm{~mm}$ long; lower lip 3-lobed. shortly ciliate on margins $(\times 10$ lens), the middle lobe oblong-obovate. $8-10 \times 5-7 \mathrm{~mm}$, abruptly slightly expanded distally at the middle, the distal half broadly orbicular, retuse at apex, the auriculate base attenuate into a short stipe; lateral lobes longitudinally reniform, $10 \times 6 \mathrm{~mm}$, directed slightly backward; staminal filaments inserted at the top of the corolla tube, ca. $10 \mathrm{~mm}$ long, 2 anterior ones sparsely pilose, 2 posterior ones glabrous. anthers ellipsoid; style slightly exserted from beak. Capsule and seeds unknown.

Etymology. The new species is named for the lype locality, Yaoshan Mountain of Yumnan Province. China.

Distribution and ecology. Pedicularis yaoshanensis is probably an endemic species; it has only been collected at the type locality in the Yaoshan Mountain, northeastern Yumnan. According to field investigations, only one population of this new species was found. There are approximately 100 mature individuals observed on the wet cliffs.

Relationships. Pedicularis yaoshanensis differmarkedly from previously known species in the genus. It shows resemblances to species belonging to two different series of the genus, series Pumiliones Prain and series Longiflorae Prain. In its dwarf habil. petiolate leaves, rather long corolla tubes, and corollas with broad, plump lower lips, P. yaoshanensis resembles the species placed in series Pumiliones. This series comprises two species: P. przewalskii Maximowicz (endemic to northwestern and southwestem China, in alpine meadows) and $P$. bella Hooker $f$. (distributed in Tibet (Xizang, China) and Sikkim, in alpine meadows, steep slopes, and cliff faces). However, P. yaoshanensis differs from both these species by pinnatipartite leaves, deflexed galea beak obliquely pointing downward, and glabrous posterior filaments. It is clearly distinguished additionally from $P$. bella by glabrous leaves, a 3-lobed calyx, and especially a different corolla structure. In $P$. bella, the middle lobe of the corolla lower lip is much smaller than the laterals, which curve upward and hide the galea (see photograph: Ree, 2005, fig. 4). whereas in $P$. yaoshanensis the middle lobe of the corolla lower lip is the same size as the lateral ones and the whole lower lip is outspread, not concealing the galea. Its 3-lobed calyx also distinguishes $P$. yashanensis from most infraspecific laxa within $P$. przewalskii, except for P. przewalskii subsp. microphyton (Bureau \& Franchet) P. C. T'soong $(=P$. microphyton Bureau \& Franchet). This subspecies has two varieties: variety microphyton has a white or pale yellow lower corolla lip that is not ciliate, while variety purpurea (Bonati) P. C. Tsoong (= P. coppeyi Bonati) from Sichuan has an entirely purple corolla with ciliate lower lip (H.-B. Yang et al., 1998). Pedicularis yaoshanensis, on the other hand, has a white corolla throat and a ciliate lower lip, thus combining characters of both varieties of $P$. przewalskii subsp. microphyton. However, Pedicularis yaoshanensis differs additionally from all infraspecific taxa of P. przewalskii by long conical roots, revolute leaf margins, and posterior calyx lobe smaller than the other two and tripartite.

In its 3-lobed calyx and corolla with a falcately curved beak. Pedicularis yaoshanensis resembles members of series Longiflorae more than it does series Pumiliones. Series Longiflorae is a large series of about 22 species, 19 of them occurring in China (H.-B. Yang el al., 1998: Yamazaki. 2003). All previously described species of this series whose habital is known are plants of alpine meadows. often 
in swampy habitats; P. yaoshanensis is apparently unique in occupying wet cliffs. Within series Longiflorae, $P$. yaoshanensis most resembles $P$. humilis Bonati, $P$. latituba Bonati, $P$. lobatorostrata T. Yamazaki, P. sigmoidea Franchet ex Maximowicz, and $P$. siphonantha D. Don on account of the emarginate corolla lower lip. Those five species are the only ones currently placed in series Longiflorae to have the combination of red-purple or pink corolla and an emarginate labellum. Neither species of series Pumiliones has an emarginate labellum, indicating that $P$. yaoshanensis is better placed in series Longiflorae, where the character state does occur. Its acaulescent habit easily separates $P$. yaoshanensis from $P$. humilis (which, despite the specific epithet, has stems $5-15 \mathrm{~cm}$ tall), $P$. sigmoidea, and $P$. siphonantha. Only P. latituba and P. lobatorostrata have stems typically not more than $3 \mathrm{~cm}$ tall and could be confused, in that respect, with P. yaoshanensis. Pedicularis yaoshanensis has a much smaller calyx than either of those species; its tube is only 5$6 \mathrm{~mm}$ long, as opposed to $8-10 \mathrm{~mm}$ in P. latituba and $13-20 \mathrm{~mm}$ in $P$. lobatorostrata. Pedicularis yaoshanensis also differs from both these species in glabrous posterior staminal filaments, although this character does occur in some species of series Longiflorae that lack the combination of acaulescent stem, red corolla, and emarginate labellum. Pedicularis latituba has a very distinctive bicolored corolla, the central area of each lobe of the labellum being a much deeper purple than the outer area. This further distinguishes it from P. yaoshanensis, which has the central area of the labellum paler or whitish, not darker. Pedicularis yaoshanensis resembles $P$. lobatorostrata in being dwarf and almost acaulescent (in P. lobatorostrata there is a $1.5-3 \mathrm{~cm}$ stem, whereas in P. yaoshanensis the stem is virtually absent) and in having red-purple corollas with long tubes 32-45 mm long and a deeply bilobed galea. However, P. lobatorostrata has a 5-lobed calyx, which is unusual in series Longiflorae and distinguishes it from both $P$. yaoshanensis (calyx with 3 lobes) and $P$. latiluba (calyx with 2 or 3 lobes). Pedicularis lobatorostrata is additionally distinguished from $P$. yaoshanensis by its relatively narrower leaves, which are about 3-5 times (not 1.8-2.5 times) as long as broad.

The key below serves to identify Pedicularis yaoshanensis and the taxa mentioned in the discussion above. It includes all taxa belonging to series Pumiliones, but only those Chinese species of series Longiflorae having a red-purple corolla with an emarginate labellum and a stem less than $5 \mathrm{~cm}$ tall.
Key to Similar Species withiv Pedicularis Series Lovgiflorae aND PUMLIONES

1a. Middle lobe of labellum emarginate; filaments either all pubescent or 2 glabrous (ser. Longiflorae)

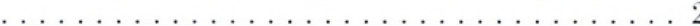

1b. Middle lobe of labellum entire; all 4 filaments pubescent (ser. Pumiliones) . . . . . . . . . . . 4

2a. Calyx tube $13-20 \mathrm{~mm}$ long, with 5 lobes at apex ............. lobatorostrata

2b. Calyx tube $5-10 \mathrm{~mm}$ long, with 2 or 3 lobes at apex......................

3a. Galea beak arcuate but not forming a semicircle, deeply bilobed at apex; calyx tube 5-6 mm long; 2 posterior filaments glabrous...... P. yaoshanensis

3b. Galea beak forming a semicircle, not deeply bilobed at apex; calyx tube 8$10 \mathrm{~mm}$ long: all filaments pubescent ................. latituba

4a. Corolla labellum suberect and curved upward, partly hiding galea: galea beak S-shaped, entire, ca. $8 \mathrm{~mm}$ long ........... bella

4b. Corolla labellum spreading, not concealing galea; galea beak straight, 2-cleft, 5-6 mm long... $\ldots \ldots \ldots \ldots$ (P. przewalskii $) 5$

5a. Corolla \pm entirely deep purple except sometimes for whitish throat .............6

5b. Corolla with dark galea and pale purple, cream, or whitish

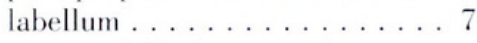
6a. Leaf blades sparsely pubescent to glabrous .... .........P. przewalskii subsp. przewalskii var. przewalskii

6b. Leaf blades densely pubescent .......... P. przewalskii subsp. australis 7a. Calyx with 2 or 3 lobes.... . P. przewalskii subsp. microphyton

7b. Calyx with 5 lobes ...8 8a. Leaves glabrous or sparsely pubescent...... .... P. przewalskii subsp. przewalskii var. cristata

8b. Leaves densely pubescent ... .... P. przewalskii subsp. hirsuta

Paratype. CHINA. Yumnan: Qiaojia county, Yaoshan Mountain, $27^{\circ} 11^{\prime} \mathrm{N}, 103$ 04'E, 3700 m, 17 Aug. 2004, Hong Wang \& Shu-dong Zhang 03-0840A (KUN, MO).

Acknowledgments. We are grateful to Qin Lin, Jie Cai, and $\mathrm{Na}-\mathrm{Na}$ Lin for their help in the fieldwork in northeastern Yunnan, and to the curator of KUN for making the specimen available. We are indebted to $\mathrm{Xi}_{\mathrm{i}}$ Lin $\mathrm{Wu}$, botanical artist, for the drawings. This project was supported by the National Natural Science 
Foundation of China (30570115). The Royal Botanic Garden Edinburgh is supported by the Scottish Executive Environment and Rural Affairs Department.

\section{Literalure Cited}

Li. H.-L.. 1951. Evolution in the flowers of Pedicularis. Evolution 5: 158-164.

Li, W.-L.. H. Wang \& D.-Z. Li. 2002. Biogeography and species diversity of Pedicularis (Scrophulariaceae) of Yunnan. Acta Bot. Yunnan. 24: 583-590.

Macior, L. W. 1988. A preliminary study of the pollination ecology of Pedicularis (Scrophulariaceae) in Japan. Pl. Spec. Biol. 3: 61-66.

Mill, R. R. 2001. Notes relating to the flora of Bhutan: XIIII. Scrophulariaceac (Pedicularis). Edinburgh J. Bot. 58: $57-98$.

Ree, R. 2005. Phylogeny and the evolution of floral diversity in Pedicularis (Orobanchaceae). Int. J. Pl. Sci. 166: $595-613$.

Wang. H. 2005. Pedicularis. In: Flora Yunnanica 18. Science Press, Beijing.
R. R. Mill \& S. Blackmore. 2003. Pollen morphology and infra-generic evolutionary relationships in some Chinese species of Pedicularis (Scrophulariaceae). Pl. Syst. Evol. 237: 1-17.

Wu. Z.-Y.. A.-M. Lu. Y.-C. Tang. Z.-D), Chen \& D.-Z. Li. 2003. The Families and Genera of Angiosperms in China. A Comprehensive Analysis. Science Press, Beijing.

Yamazaki. T. 2000 . Seven new species of the genus Pedicularis (Scrophulariaceae) from Tibet (Xizang) and its adjacent region in China. J. Jap. Bot. 75: 21:3-222. 2001. Two new species of the genus Pedicularis (Scrophulariaceae) from SW China. J. Jap. Bot. 76: 96-99 2003. New species of Pedicularis (Scrophulariaceae) from Westem China and amendment for names of Pedicularis from Bhulan. J. Jap. Bot. 78: 198-202.

Yang. F.-S., D.-Y. Hong \& X.-Q. W Wang. 2003. A new species and a new specific synonym of Pedicularis (Scrophulariaceae) from the Hengduan Mountains. China. Novon 13: $36.3-367$.

Yang. H.-B.. N. H. Holmgren \& R. R. Mill. 1998. Pedicularis. Pp. 97-209 in Z.- Y. Wu \& P. H. Raven (editors), Flora of China. Vol. 18. Science Press, Beijing. and Missouri Bolanical Garden Press, St. Louis. 

Volume 16. Number 2. pp. 161-292 of NOVON was published on 26 July 2006. 


\section{$2 \mathrm{BHL}$ Biodiversity Heritage Library}

Zhang, Shu-Dong, Wang, Hong, and Mill, Robert R. 2006. "A New Species of Pedicularis (Scrophulariaceae) from the Yaoshan Mountain, Yunnan, China." Novon a journal of botanical nomenclature from the Missouri Botanical Garden 16, 286-292.

View This Item Online: https://www.biodiversitylibrary.org/item/41804

Permalink: https://www.biodiversitylibrary.org/partpdf/121794

\section{Holding Institution}

Missouri Botanical Garden, Peter H. Raven Library

\section{Sponsored by}

Missouri Botanical Garden

\section{Copyright \& Reuse}

Copyright Status: In copyright. Digitized with the permission of the rights holder.

License: http://creativecommons.org/licenses/by-nc-sa/3.0/

Rights: https://biodiversitylibrary.org/permissions

This document was created from content at the Biodiversity Heritage Library, the world's largest open access digital library for biodiversity literature and archives. Visit BHL at https://www.biodiversitylibrary.org. 